\title{
Optimasi Penempatan Petugas Keamanan Di Taman Safari Prigen Pasuruan Menggunakan Teori Himpunan Dominasi
}

\author{
Reni Umilasari ${ }^{1}$, Ilham Saifudin ${ }^{2}$, Reza Fachruddin Azhar ${ }^{3}$ \\ Program Studi Teknik Informatika, Fakultas Teknik Universitas Muhammadiyah Jember \\ reni.umilasari@unmuhjember.ac.id ${ }^{1}$, ilham.saifudin@unmuhjember.ac.id ${ }^{2}$, \\ fachruddin.reza@gmail.com ${ }^{3}$
}

(Naskah masuk: 20 Juni 2019, diterima untuk diterbitkan: 5 Juli 2019)

\begin{abstract}
ABSTRAK
Taman Safari Prigen dengan luas 350 hektar merupakan kebun binatang yang mempunyai konsep alam terbuka, sehingga pengunjung harus menggunakan mobil pribadi, mobil wisata, atau tramp yang disediakan. Mengingat begitu luas dan banyaknya spesies yang terdapat di Taman Safari tentu saja rute yang dilalui pengunjung juga sangat panjang. Petugas keamanan biasanya stand by menggunakan mobil jib pada setiap jalan atau tikungan. Oleh karena itu, perlu adanya inovasi untuk mengoptimasi penempatan petugas dan armada sehingga lebih meminimalisir jumlah petugas dengan tanpa mengurangi fungsi atau fasilitas keamanan yang seharusnya. Misalnya satu petugas dengan satu armada dapat mendominasi atau bertugas terhadap keamanan pada dua wiliyah terdekat yang dapat dijangkau. Hal ini sesuai dengan teori himpunan dominasi jarak dua pada suatu graf.

Graf yang akan digunakan dalam penelitian ini merupakan representasi dari peta lokasi kebun binatang Taman Safari Prigen dengan vertex merupakan posisi/lokasi petugas keamanan sedangkan sisi merupakan jalan yang dapat dilalui mobil untuk jalur pengunjung serta fasilitas keamanan. Selain itu, implementasi teori dari himpunan dominasi juga akan diteliti pada beberapa graf yaitu graf platonik yang dioperasikan shackle titik dengan graf yang sama. Graf Platonik terdiri atas graf tetrahedral, octahedral, kubik, icosahedral dan dodecahedral.

Penelitian diawali dengan penentuan representasi graf hasil operasi, himpunan simpul elemen himpunan dominasi jarak dua untuk kemudian ditentukan banyaknya bilangan dominasi jarak dua. Setelah itu, teori yang telah digunakan dapat diaplikasikan untuk menentukan banyaknya pos pengamanan yang optimal yang dapat ditempatkan di kebun binatang Taman Safari Prigen.
\end{abstract}

Kata kunci: himpunan dominasi, graf platonik, operasi shackle, taman safari prigen

\section{ABSTRACT}

Prigen Safari Park with an area of 350 hectares carrying the concept of an African-style zoo that allows animals to be free in the open. So to see animals, visitors must use a private car, tourist car, or tramp provided. Given the vast and numerous species found in the Safari Park, of course the route traveled by visitors is also very long. So that security guard posts that are alerted must also be adjusted. Security post usually stand by using a jib on every street or bend so this causes the staff and fleet to be prepared very much. Therefore, innovation is needed to optimize the placement of officers and fleets so as to minimize the number of security post without reducing the function or security facilities that should be. For example, one post with a fleet can dominate or be tasked with security at the two closest regions that can be reached. This is in accordance with the theory of dominating set of distance two on a graph.

The graph that be used in this study is a representation of the map of the location of the Safari Park Prigen with vertex is a position / location that can be occupied by security post while the side (edge) is a road or path that can be traversed by cars for visitor lanes and security facilities. In addition, the implementation of the theory of the dominating set of distance two will also be examined in several graphs, namely platonic graphs operated by vertex shackle products by the same graph. The Platonic graphs consists of tetrahedral graphs, octahedral graphs, cubic graphs, icosahedral graphs, dodecahedral graphs.

The study began by determining the graph which operated by vertex shackle product, after that finding the vertex set of dominating set of distance two and calculating the minimum cardinality or determining the dominating number of distance two. At the last step, the theory that has been used 
can be applied to determine the optimal number of security posts that can be placed in the Taman Safari Prigen zoo by first depicting a map representation of the Taman Safari Prigen zoo.

Keywords: dominating set, platonic graph, vertex shackle product, safari prigen park.

\section{PENDAHULUAN}

Taman Safari Indonesia merupakan salah satu kebun binatang yang berada di Pasuruan, lebih tepatnya berada di Desa Jatiarjo RT.12/RW.06, Prigen. Wisata di Pasuruan ini merupakan safari park terluas di Asia dengan luas sekitar 350 hektare. Tempatnya berada di lereng kaki Gunung Arjuno yang membuatnya memiliki suhu yang dingin. Di kebun binatang ini, pengunjung dapat melihat secara langsung bagaimana satwa liat beraktivitas di habitatnya masing-masing, sekaligus menikmati segarnya udara lereng Pegunungan Arjuno. Untuk melihat satwa, pengunjung harus menggunakan mobil pribadi, mobil wisata, atau tramp yang disediakan. Sedangkan untuk ke zonazona lainnya, tentu pengunjung harus berjalan kaki. Di dalam Taman Safari Prigen terdapat lebih dari 2000 spesies langka. Banyak aktivitas menarik yang dapat dilakukan di kebun binatang tersebut selain melihat binatang-binatang dari dekat, diantaranya animal education show, wahana bermain, kolam renang, Amusement Park, Safari Paintball, Tiger Cave Restauran, recreation area dan lainlain.

Mengingat begitu luas dan banyaknya spesies yang terdapat di Taman Safari tentu saja rute yang dilalui pengunjung juga sangat panjang. Sehingga pos-pos petugas keamanan yang disiagakan juga harus disesuaikan. Petugas keamanan biasanya stand by menggunakan mobil jib pada setiap jalan atau tikungan sehingga hal ini menyebabkan petugas dan armada yang disiapkan sangat banyak. Oleh karena itu, perlu adanya inovasi optimasi penempatan petugas dan armada sehingga lebih meminimalisir jumlah petugas dengan tanpa mengurangi fungsi atau fasilitas keamanan yang seharusnya. Misalnya satu petugas dengan satu armada dapat mendominasi atau bertugas terhadap keamanan pada dua wiliyah terdekat yang dapat dijangkau. Hal ini sesuai dengan teori bilangan bilangan dominasi jarak dua pada suatu graf.

Dominasi

secara matematis dikenalkan pada awal tahun 1960. Sejak saat itu baik himpunan dominasi maupun bilangan dominasi banyak digunakan dalam berbagai aplikasi. Salah satu contoh aplikasi dari bilangan dominasi adalah menentukan banyaknya dan posisi strategis untuk Penempatan Anjungan Tunai Mandiri (ATM) pada Kecamatan Sumbersari Kabupaten Jember Menggunakan Teori Bilangan Dominasi (Saifudin, I dan Umilasari, R; 2017).

Secara teoritif untuk setiap graf $G=$ $(V, E), S \subseteq V(G)$ dapat dikatakan himpunan dominasi dari $G$ jika setiap simpul $u \in V(G)$ bertetangga dengan $S$. Dengan demikian untuk setiap simpul $u \in V(G)$, ada simpul $v$ $\in S$ dimana jarak antara $u$ dan $v$ maksimal satu. Kardinalitas minimum pada himpunan dominasi di graf $G$ disebut dengan bilangan dominasi. Pada paper ini akan ditentukan himpunan dominasi jarak dua pada graf $G$ yang didefinisikan dengan $S 2 \subseteq V(G)$, dimana untuk setiap simpul $u \in V(G)$ ada simpul $w \in S 2$ dimana jarak antara $u$ dan $w$ maksimal dua. Kardinalitas minimum pada himpunan dominasi jarak dua di graf $G$ disebut dengan bilangan dominasi jarak dua. 
Graf yang akan digunakan dalam penelitian ini merupakan representasi dari peta lokasi kebun binatang Taman Safari Prigen dengan vertex merupakan posisi/lokasi yang dapat ditempati oleh petugas keamanan sedangkan sisi (edge) merupakan jalan atau lintasan yang dapat dilalui mobil untuk jalur pengunjung serta fasilitas keamanan. Selain itu, implementasi teori dari himpunan dominasi juga akan diteliti pada beberapa graf yaitu graf platonik yang dioperasikan shackle titik dengan graf yang sama. Graf Platonik yang akan dicari bilangan dominasi jarak duanya terdiri atas graf Tetrahedral, graf Oktahedral, graf Kubik, graf Icosahedral dan graf Dodecahedral

\section{METODE PENELITIAN}

Metode yang digunakan dalam penelitian ini adalah pendeteksian pola, yaitu dengan cara mencari himpunan dominasi sedemikian hingga ditemukan bilangan kardinalitas yang minimum. Selain itu metode yang digunakan dalam penelitian ini adalah deduktif aksiomatik yaitu metode penelitian yang menggunakan prinsip-prinsip pembuktian deduktif yang berlaku dalam logika matematika dengan menggunakan aksioma atau teorema yang telah ada untuk memecahkan masalah. Penelitian ini akan menghasilkan teorema-teorema baru yang telah dibuktikan secara deduktif sehingga kebenarannya berlaku secara umum. Adapun alur tahapan penelitian dapat dilihat sebagai berikut:

1. Menentukan graf hasil operasi shackle titik antar garf platonik;

2. menentukan dominating set pada graf hasil operasi tersebut;

3. memilih simpul berderajat maksimal sebagai simpul pendominasi jarak dua;

4. memilih simpul berderajat maksimal berikutnya yang belum terdominasi;

5. menentukan himpunan dominasi jarak dua;
6. menentukan bilangan kardinalitas jarak dua;

7. pengamatan peta lokasi taman safari prigen

8. merepresentasikan peta ke dalam graf

9. menentukan banyaknya bilangan dominasi seperti langkah (2.) sampai (6.)

\section{HASIL}

\subsection{Bilangan Dominasi Jarak Dua pada Graf Platonik}

Teorema 1. Bilangan dominasi jarak dua pada graf Tetrahedral $P_{3^{3}}$ sebanyak $n$ salinan dengan operasi shackle titik adalah

Bukti.

$$
\gamma_{2}\left(\operatorname{Shack}\left(P_{3^{3}}, v, n\right)\right)=\left\lceil\frac{n}{4}\right\rceil
$$

$\operatorname{Shack}\left(P_{3^{3}}, v, n\right)$ adalah graf Tetrahedral yang dioperasikan shackle titik sebanyak $n$ salinan dengan $v$ sebagai lingkage vertex. Graf Tetrahedral merupakan graf platonik dengan 4 simpul. Dengan demikian, banyaknya simpul dari $\operatorname{Shack}\left(P_{3^{3}}, v, n\right)$ adalah $4 n-n+1$ simpul atau $3 n+1$ simpul.

Graf tetrahedral merupakan graf yang berdiameter 1 , sehingga jika dioperasikan shackle titik maka sebuah simpul pendominasi dapat mendominasi maksimal 4 salinan graf $G$, sehingga jumlah simpul pendominasi yang dibutuhkan adalah $\gamma_{2}\left(\operatorname{Shack}\left(P_{3^{3}}, v, n\right)\right)=\left\lceil\frac{n}{4}\right\rceil \quad$ dengan $\operatorname{diam}(G)=1$.

Selanjutnya akan ditunjukkan bahwa $\left\lceil\frac{n}{4}\right\rceil$ adalah simpul pendominasi minimal yang dapat mendominasi semua simpul pada $\operatorname{Shack}\left(P_{3^{3}}, v, n\right)$ dengan $\operatorname{diam}(\mathrm{G})=1$. Andai $\gamma_{2}\left(\operatorname{Shack}\left(P_{3^{3}}, v, n\right)\right)=\left\lceil\frac{n}{4}\right\rceil-1$, maka salinan maksimal yang dapat didominasi sampai jarak 2 adalah

$$
4 n\left(\left\lceil\frac{n}{4}\right\rceil-1\right) \leq 4 n\left(\frac{n+4 n-1}{4 n}-1\right)=n-1
$$


Dengan demikian jumlah salinan maksimal yang dapat didominasi adalah $n-1$ sehingga terdapat minimal satu salinan graf yang tidak dapat didominasi, maka $\gamma_{2}\left(\operatorname{Shack}\left(P_{3^{3}}, v, n\right)\right) \neq\left\lceil\frac{n}{4}\right\rceil-1$. Karena $\left\lceil\frac{n}{4}\right\rceil$ adalah jumlah simpul pendominasi minimal yang dapat mendominasi seluruh simpul $\operatorname{Shack}\left(P_{3^{3}}, v, n\right)$ maka terbukti $\gamma_{2}\left(\operatorname{Shack}\left(P_{3^{3}}, v, n\right)\right)=\left\lceil\frac{n}{4}\right\rceil$.

Teorema 2. Bilangan dominasi jarak dua pada graf Oktahedral $P_{3^{4}}$ sebanyak $n$ salinan dengan operasi shackle titik adalah

Bukti.

$$
\gamma_{2}\left(\operatorname{Shack}\left(P_{3^{4}}, v, n\right)\right)=\left\lceil\frac{n}{2}\right\rceil
$$

Sebuah graf $G$ berdiamater 2 jika dioperasikan shackle titik maka sebuah simpul pendominasi dapat mendominasi maksimal 2 salinan graf $G$, sehingga jumlah simpul pendominasi yang dibutuhkan adalah $\gamma_{2}\left(P_{3^{3}}, v, n\right)=\left\lceil\frac{n}{2}\right\rceil$ dengan $\operatorname{diam}(G)=2$. Selanjutnya akan ditunjukkan bahwa $\left\lceil\frac{n}{2}\right\rceil$ adalah simpul pendominasi minimal yang dapat mendominasi semua simpul pada $\operatorname{Shack}\left(P_{3^{3}}, v, n\right)$. Andai $\gamma_{2}\left(\operatorname{Shack}\left(P_{3^{3}}, v, n\right)\right)=\left\lceil\frac{n}{2}\right\rceil-1, \quad$ maka salinan maksimal yang dapat didominasi sampai jarak 2 adalah

$$
\begin{aligned}
\left.2 n\left(\mid \frac{n}{2}\right\rceil-1\right) \leq & 2 n\left(\frac{n+2 n-1}{2 n}-1\right) \\
& =n-1
\end{aligned}
$$

Dengan demikian jumlahsalinan maksimal yang dapat didominasi adalah $n-1$ sehingga tidak semua simpul pada graf $\operatorname{hack}\left(P_{3^{3}}, v, n\right) \quad$ didominasi, maka $\gamma_{2}\left(\operatorname{Shack}\left(P_{3^{3}}, v, n\right)\right) \neq\left\lceil\frac{n}{2}\right\rceil-1$. Karena $\left\lceil\frac{n}{2}\right\rceil$ adalah jumlah simpul pendominasi minimal yang dapat mendominasi seluruh simpul $\operatorname{Shack}\left(P_{3^{3}}, v, n\right)$ maka $\gamma_{2}\left(\operatorname{Shack}\left(P_{3^{3}}, v, n\right)\right)=\left\lceil\frac{n}{2}\right\rceil$.
Teorema 3. Bilangan dominasi jarak dua pada graf Kubik $P_{4^{3}}$ sebanyak $n$ salinan dengan operasi shackle titik adalah

$$
\gamma_{2}\left(\operatorname{Shack}\left(P_{4^{3}}, v, n\right)\right)=\gamma_{2}\left(P_{4^{3}}\right) n-n+1
$$

\section{Bukti.}

Terdapat dua kemungkinan simpul-simpul himpunan dominasi jarak dua pada graf Kubik, yaitu $v \in \mathrm{S} 2$ dan $v$ bukan elemen $S_{2}$ dengan $v$ adalah simpul penghubung (lingkage vertex) antara $P_{4^{3}}$ salinan ke- $i$ dan $P_{4^{3}}$ salinan ke- $i+1$, sedangkan $S_{2}$ adalah himpunan simpul pendominasi jarak dua pada graf $P_{4^{3}}$. Berikut akan diuraikan untuk masing-masing kasus.

\section{Kasus 1. $v \in \mathrm{S} 2$}

Pada kasus dimana $v \in S_{2}$ untuk jumlah salinan ke-1 sampai salinan ke- $n$, bilangan dominasi jarak dua pada $\operatorname{Shack}\left(P_{4^{3}}, v, n\right)$ akan membentuk barisan aritmatika sebagai berikut.

$$
\begin{aligned}
n= & \rightarrow \gamma_{2}\left(P_{4^{3}}\right) \\
n=2 \rightarrow & 2 \gamma_{2}\left(P_{4^{3}}\right)-2+1=2 \gamma_{2}\left(P_{4^{3}}\right)-1 \\
n= & \rightarrow 3 \gamma_{2}\left(P_{4^{3}}\right)-3+1=3 \gamma_{2}\left(P_{4^{3}}\right)-2 \\
& \cdots \\
n= & n \rightarrow \gamma_{2}\left(P_{4^{3}}\right) n-n+1
\end{aligned}
$$

Maka dengan menggunakan barisan aritmatika akan didapat bilangan dominasi jarak dua dari graf hasil operasi shackle titik sebanyak $n$ salinan adalah $\gamma_{2}\left(P_{4^{3}}\right) n-$ $n+1$. Selanjutnya akan dibuktikan bilangan dominasi tersebut dengan menggunakan induksi matematika sebagai berikut.

$$
\gamma_{2}\left(\operatorname{Shack}\left(P_{4^{3}}, v, n\right)\right)=\gamma_{2}\left(P_{4^{3}}\right) n-n+1
$$

Akan dibuktikan untuk $n=1$ adalah benar

$$
\begin{gathered}
\gamma_{2}\left(\operatorname{Shack}\left(P_{4^{3}}, v, 1\right)\right)=\gamma_{2}\left(P_{4^{3}}\right) \cdot 1-1+1 \\
\Leftrightarrow \gamma_{2}\left(P_{4^{3}}\right)=\gamma_{2}\left(P_{4^{3}}\right)
\end{gathered}
$$

Asumsikan untuk $n=k$ adalah benar

$$
\begin{gathered}
\gamma_{2}\left(\operatorname{Shack}\left(P_{4^{3}}, v, k\right)\right)=\gamma_{2}\left(P_{4^{3}}\right) \cdot k-k+1 \\
\Leftrightarrow \gamma_{2}\left(P_{4^{3}}, v, k\right)=\gamma_{2}\left(P_{4^{3}}\right) \cdot k-k+1
\end{gathered}
$$

Akan dibuktikan untuk $n=k+1$ juga benar

$$
\begin{aligned}
\gamma_{2}\left(\operatorname { S h a c k } \left(P_{4^{3}},\right.\right. & v, k+1)) \\
& =\gamma_{2}\left(\operatorname{Shack}\left(P_{4^{3}}, v, k\right)\right) \\
& + \text { beda }
\end{aligned}
$$




$$
\begin{aligned}
& \Leftrightarrow \gamma_{2}\left(P_{4^{3}}\right) \cdot(k+1)-(k+1)+1= \\
& \gamma_{2}\left(P_{4^{3}}\right) \cdot k-k+1+\gamma_{2}\left(P_{4^{3}}\right)-1 \\
& \Leftrightarrow \gamma_{2}\left(P_{4^{3}}\right) \cdot(k+1)-k-1+1=\gamma_{2}\left(P_{4^{3}}\right) . \\
& k-k+1+\gamma_{2}\left(P_{4^{3}}\right)-1 \\
& \Leftrightarrow \gamma_{2}\left(P_{4^{3}}\right) \cdot(k+1)-k=\gamma_{2}\left(P_{4^{3}}\right) \cdot \\
& (k+1)-k \\
& \Leftrightarrow \gamma_{2}\left(P_{4^{3}}\right) \cdot k+\gamma_{2}\left(P_{4^{3}}\right)-k=\gamma_{2}\left(P_{4^{3}}\right) \cdot k+ \\
& \gamma_{2}\left(P_{4^{3}}\right)-k
\end{aligned}
$$

Dengan demikian terbukti bahwa pada kasus $v \in S_{2}$, operasi shackle titik pada graf kubik memiliki $\gamma_{2}\left(\operatorname{Shack}\left(P_{4^{3}}, v, n\right)\right)=$ $\gamma_{2}\left(P_{4^{3}}\right) n-n+1$.

Kasus 2. $v \notin S_{2}$

Pada kasus dimana $v$ bukan elemen $S_{2}$ untuk jumlah salinan ke-1 sampai salinan ke- $n$, bilangan dominasi jarak dua pada $\operatorname{Shack}\left(P_{4^{3}}, v, n\right)$ akan membentuk barisan aritmatika sebagai berikut.

$$
\begin{aligned}
n=1 \rightarrow & \gamma_{2}\left(P_{4^{3}}\right) \\
n=2 \rightarrow & 2 \gamma_{2}\left(P_{4^{3}}\right) \\
n=3 \rightarrow & 3 \gamma_{2}\left(P_{4^{3}}\right) \\
& \cdots \\
n= & \cdots \\
& \gamma_{2}\left(P_{4^{3}}\right) \cdot n
\end{aligned}
$$

Maka dengan menggunakan barisan aritmatika akan didapat bilangan dominasi jarak dua dari graf hasil operasi shackle titik pada sebanyak $n$ salinan adalah $\gamma_{2}\left(P_{4^{3}}\right) \cdot n$. Berikutnya akan dibuktikan bilangan dominasi tersebut dengan menggunakan induksi matematika sebagai berikut.

$$
\gamma_{2}\left(\operatorname{Shack}\left(P_{4^{3}}, v, n\right)\right)=\gamma_{2}\left(P_{4^{3}}\right) n
$$

Akan dibuktikan untuk $n=1$ adalah benar

$$
\begin{aligned}
& \gamma_{2}\left(\operatorname{Shack}\left(P_{4^{3}}, v, 1\right)\right)=\gamma_{2}\left(P_{4^{3}}\right) \cdot 1 \\
& \Leftrightarrow \gamma_{2}\left(P_{4^{3}}\right)=\gamma_{2}\left(P_{4^{3}}\right)
\end{aligned}
$$

Asumsikan untuk $n=k$ adalah benar

$$
\gamma_{2}\left(\operatorname{Shack}\left(P_{4^{3}}, v, k\right)\right)=\gamma_{2}\left(P_{4^{3}}\right) \cdot k
$$

Akan dibuktikan untuk $n=k+1$ juga benar $\gamma_{2}\left(\operatorname{Shack}\left(P_{4^{3}}, v, k+1\right)\right)$

$$
\begin{aligned}
& =\gamma_{2}\left(\operatorname{Shack}\left(P_{4^{3}}, v, k\right)\right) \\
& +\operatorname{beda}
\end{aligned}
$$

$\Leftrightarrow \gamma_{2}\left(P_{4^{3}}\right)(k+1)=\gamma_{2}\left(P_{4^{3}}\right) k+\gamma_{2}\left(P_{4^{3}}\right)$

$\Leftrightarrow \gamma_{2}\left(P_{4^{3}}\right)(k)+\gamma_{2}\left(P_{4^{3}}\right)(1)=\gamma_{2}\left(P_{4^{3}}\right) k+\gamma_{2}\left(P_{4^{3}}\right)$

$\Leftrightarrow \gamma_{2}\left(P_{4^{3}}\right)(k)+\gamma_{2}\left(P_{4^{3}}\right)=\gamma_{2}\left(P_{4^{3}}\right) k+\gamma_{2}\left(P_{4^{3}}\right)$
Dengan demikian untuk $v \notin S_{2}$, hasil operasi shackle titik graf kubik memiliki $\gamma_{2}\left(\operatorname{Shack}\left(P_{4^{3}}, v, n\right)\right)=\gamma_{2}\left(P_{4^{3}}\right) n$. Dari kasus 1 dan 2 dapat diketahui bahwa $\gamma_{2}\left(P_{4^{3}}\right) n-$ $n+1 \leq \gamma_{2}\left(P_{4^{3}}\right) n \quad$ maka $\gamma_{2}\left(\operatorname{Shack}\left(P_{4^{3}}, v, n\right)\right)=\gamma_{2}\left(P_{4^{3}}\right) n-n+1$.

Selanjutnya akan dibuktikan bahwa $\gamma_{2}\left(\operatorname{Shack}\left(P_{4^{3}}, v, n\right)\right)=\gamma_{2}\left(P_{4^{3}}\right) n-n+1$

adalah jumlah simpul pendominasi minimal pada graf $\operatorname{Shack}\left(P_{4^{3}}, v, n\right)$. Andaikan $\left|S_{2} \operatorname{Shack}\left(P_{4^{3}}, \mathcal{v}, n\right)\right|=\gamma_{2}\left(P_{4^{3}}\right) n-n+1-1$ maka simpul maksimal yang dapat didominasi oleh $\left|S_{2}\right|$ adalah

$$
\begin{gathered}
1+\left(N_{1}+N_{2}\right) n\left(\left[\frac{8 n-n+1}{1+\left(N_{1}+N_{2}\right) n}\right]\right) \\
\leq 1+\left(N_{1}+N_{2}\right) n \\
\left(\frac{8 n-n+1+\left(N_{1}+N_{2}\right) n}{1+\left(N_{1}+N_{2}\right) n}-1\right)=7 n
\end{gathered}
$$

Dengan demikian tidak semua simpul dapat didominasi, maka $\left|S_{2} \operatorname{Shack}\left(P_{4^{3}}, v, n\right)\right| \neq \gamma_{2}\left(P_{4^{3}}\right) n-n+1-1$. Karena $\gamma_{2}\left(P_{4^{3}}\right) n-n+1$ adalah jumlah simpul pendominasi minimal maka terbukti bahwa $\gamma_{2}\left(\operatorname{Shack}\left(P_{4^{3}}, v, n\right)\right)=\gamma_{2}\left(P_{4^{3}}\right) n-$ $n+1$.

Teorema 4. Bilangan dominasi jarak dua pada graf Icosahedron $P_{3^{5}}$ sebanyak $n$ salinan dengan operasi shackle titik adalah $\gamma_{2}\left(\operatorname{Shack}\left(P_{3^{5}}, v, n\right)\right)=\gamma_{2}\left(P_{3^{5}}\right) n-n+1$.

\section{Bukti.}

Terdapat dua kemungkinan simpul-simpul himpunan dominasi jarak dua pada graf Icosahedron, yaitu $v \in S_{2}$ dan $v$ bukan elemen $S_{2}$ dengan $v$ adalah simpul penghubung (lingkage vertex) antara $P_{3^{5}}$ salinan ke- $i$ dan $P_{3^{5}}$ salinan ke- $i+1$, sedangkan $S_{2}$ adalah himpunan simpul pendominasi jarak dua pada graf $P_{3^{5}}$. Berikut akan diuraikan untuk masingmasing kasus.

Kasus 1. $v \in S_{2}$

Pada kasus dimana $v \in S_{2}$ untuk jumlah salinan ke- 1 sampai salinan ke- $n$, bilangan 
dominasi jarak dua pada $\operatorname{Shack}\left(P_{3^{5}}, v, n\right)$ akan membentuk barisan aritmatika sebagai berikut.

$n=1 \rightarrow \gamma_{2}\left(P_{3^{5}}\right)$

$n=2 \rightarrow 2 \gamma_{2}\left(P_{3^{5}}\right)-2+1=2 \gamma_{2}\left(P_{3^{5}}\right)-1$

$n=3 \rightarrow 3 \gamma_{2}\left(P_{3^{5}}\right)-3+1=3 \gamma_{2}\left(P_{3^{5}}\right)-2$ ...

$n=n \rightarrow \gamma_{2}\left(P_{3^{5}}\right) n-n+1$

Maka dengan menggunakan barisan aritmatika akan didapat bilangan dominasi jarak dua dari graf hasil operasi shackle titik sebanyak $n$ salinan adalah $\gamma_{2}\left(P_{3^{5}}\right) n-$ $n+1$. Selanjutnya akan dibuktikan bilangan dominasi tersebut dengan menggunakan induksi matematika sebagai berikut.

$$
\gamma_{2}\left(\operatorname{Shack}\left(P_{3^{5}}, v, n\right)\right)=\gamma_{2}\left(P_{3^{5}}\right) n-n+1
$$

Akan dibuktikan untuk $n=1$ adalah benar

$$
\begin{gathered}
\gamma_{2}\left(\operatorname{Shack}\left(P_{3^{5}}, v, 1\right)\right)=\gamma_{2}\left(P_{3^{5}}\right) \cdot 1-1+1 \\
\Leftrightarrow \gamma_{2}\left(P_{3^{5}}\right)=\gamma_{2}\left(P_{3^{5}}\right)
\end{gathered}
$$

Asumsikan untuk $n=k$ adalah benar

$$
\begin{gathered}
\gamma_{2}\left(\operatorname{Shack}\left(P_{3^{5}}, v, k\right)\right)=\gamma_{2}\left(P_{3^{5}}\right) \cdot k-k+1 \\
\Leftrightarrow \gamma_{2}\left(P_{3^{5}}, v, k\right)=\gamma_{2}\left(P_{3^{5}}\right) \cdot k-k+1
\end{gathered}
$$

Akan dibuktikan untuk $n=k+1$ juga benar $\gamma_{2}\left(\operatorname{Shack}\left(P_{3^{5}}, v, k+1\right)\right)$

$$
\begin{aligned}
& =\gamma_{2}\left(\operatorname{Shack}\left(P_{3^{5}}, v, k\right)\right) \\
& +\operatorname{beda}
\end{aligned}
$$

$\Leftrightarrow \gamma_{2}\left(P_{3^{5}}\right) \cdot(k+1)-(k+1)+1=$

$\gamma_{2}\left(P_{3^{5}}\right) \cdot k-k+1+\gamma_{2}\left(P_{3^{5}}\right)-1$

$\Leftrightarrow \gamma_{2}\left(P_{3^{5}}\right) \cdot(k+1)-k-1+1=\gamma_{2}\left(P_{3^{5}}\right)$.

$k-k+1+\gamma_{2}\left(P_{3^{5}}\right)-1$

$\Leftrightarrow \gamma_{2}\left(P_{3^{5}}\right) \cdot(k+1)-k=\gamma_{2}\left(P_{3^{5}}\right)$.

$(k+1)-k$

$\Leftrightarrow \gamma_{2}\left(P_{3^{5}}\right) \cdot k+\gamma_{2}\left(P_{3^{5}}\right)-k=\gamma_{2}\left(P_{3^{5}}\right) \cdot k+$ $\gamma_{2}\left(P_{3^{5}}\right)-k$

Dengan demikian terbukti bahwa pada kasus $v \in S_{2}$, operasi shackle titik pada graf Icosahedron memiliki $\gamma_{2}\left(\operatorname{Shack}\left(P_{3^{5}}, v, n\right)\right)=\gamma_{2}\left(P_{3^{5}}\right) n-n+1$.

Kasus 2. $v \notin \boldsymbol{S}_{\mathbf{2}}$

Pada kasus dimana $v$ bukan elemen $S_{2}$ untuk jumlah salinan ke-1 sampai salinan ke- $n$, bilangan dominasi jarak dua pada
$\operatorname{Shack}\left(P_{3^{5}}, v, n\right)$ akan membentuk barisan aritmatika sebagai berikut.

$$
\begin{aligned}
n=1 \rightarrow & \gamma_{2}\left(P_{3^{5}}\right) \\
n=2 \rightarrow & 2 \gamma_{2}\left(P_{3^{5}}\right) \\
n=3 \rightarrow & 3 \gamma_{2}\left(P_{3^{5}}\right) \\
& \cdots \\
n= & \cdots \\
n & \gamma_{2}\left(P_{3^{5}}\right) \cdot n
\end{aligned}
$$

Maka dengan menggunakan barisan aritmatika akan didapat bilangan dominasi jarak dua dari graf hasil operasi shackle titik pada sebanyak $n$ salinan adalah $\gamma_{2}\left(P_{3^{5}}\right) \cdot n$. Berikutnya akan dibuktikan bilangan dominasi tersebut dengan menggunakan induksi matematika sebagai berikut.

$$
\gamma_{2}\left(\operatorname{Shack}\left(P_{3^{5}}, v, n\right)\right)=\gamma_{2}\left(P_{3^{5}}\right) n
$$

Akan dibuktikan untuk $n=1$ adalah benar

$$
\begin{aligned}
& \gamma_{2}\left(\operatorname{Shack}\left(P_{3^{5}}, v, 1\right)\right)=\gamma_{2}\left(P_{3^{5}}\right) \cdot 1 \\
& \Leftrightarrow \gamma_{2}\left(P_{3^{5}}\right)=\gamma_{2}\left(P_{3^{5}}\right)
\end{aligned}
$$

Asumsikan untuk $n=k$ adalah benar

$$
\gamma_{2}\left(\operatorname{Shack}\left(P_{3^{5}}, v, k\right)\right)=\gamma_{2}\left(P_{3^{5}}\right) \cdot k
$$

Akan dibuktikan untuk $n=k+1$ juga benar $\gamma_{2}\left(\operatorname{Shack}\left(P_{3^{5}}, v, k+1\right)\right)$

$$
\begin{array}{cc} 
& =\gamma_{2}\left(\operatorname{Shack}\left(P_{3^{5}}, v, k\right)\right) \\
& + \text { beda } \\
\Leftrightarrow & \gamma_{2}\left(P_{3^{5}}\right)(k+1)=\gamma_{2}\left(P_{3^{5}}\right) k+ \\
\gamma_{2}\left(P_{3^{5}}\right) & \\
\gamma_{2}\left(P_{3^{5}}\right) k+\gamma_{2}\left(P_{3^{5}}\right) & \\
\Leftrightarrow & \gamma_{2}\left(P_{3^{5}}\right)(k)+\gamma_{2}\left(P_{3^{5}}\right)(1)= \\
\gamma_{2}\left(P_{3^{5}}\right) k+\gamma_{2}\left(P_{3^{5}}\right) & \gamma_{2}\left(P_{3^{5}}\right)(k)+\gamma_{2}\left(P_{3^{5}}\right)=
\end{array}
$$

Dengan demikian untuk $v \notin S_{2}$, hasil operasi shackle titik graf Icosahedron memiliki $\gamma_{2}\left(\operatorname{Shack}\left(P_{3^{5}}, v, n\right)\right)=\gamma_{2}\left(P_{3^{5}}\right) n$. Dari kasus 1 dan 2 dapat diketahui bahwa $\gamma_{2}\left(P_{3^{5}}\right) n-n+1 \leq \gamma_{2}\left(P_{3^{5}}\right) n$ maka $\gamma_{2}\left(\operatorname{Shack}\left(P_{3^{5}}, v, n\right)\right)=\gamma_{2}\left(P_{3^{5}}\right) n-n+1$.

Selanjutnya akan dibuktikan bahwa $\gamma_{2}\left(\operatorname{Shack}\left(P_{3^{5}}, v, n\right)\right)=\gamma_{2}\left(P_{3^{5}}\right) n-n+1$ adalah jumlah simpul pendominasi minimal pada graf $\operatorname{Shack}\left(P_{3^{5}}, v, n\right)$. Andaikan $\left|S_{2} \operatorname{Shack}\left(P_{3^{5}}, v, n\right)\right|=\gamma_{2}\left(P_{3^{5}}\right) n-n+1-1$ maka simpul maksimal yang dapat didominasi oleh $\left|S_{2}\right|$ adalah 


$$
\begin{gathered}
1+\left(N_{1}+N_{2}\right) n\left(\left[\frac{12 n-n+1}{1+\left(N_{1}+N_{2}\right) n}\right]\right) \\
\leq 1+\left(N_{1}+N_{2}\right) n \\
\left(\frac{12 n-n+1+\left(N_{1}+N_{2}\right) n}{1+\left(N_{1}+N_{2}\right) n}-1\right)=11 n
\end{gathered}
$$

Dengan demikian tidak semua simpul dapat didominasi, maka $\left|S_{2} \operatorname{Shack}\left(P_{3^{5}}, v, n\right)\right| \neq \gamma_{2}\left(P_{3^{5}}\right) n-n+1-1$. Karena $\gamma_{2}\left(P_{3^{5}}\right) n-n+1$ adalah jumlah simpul pendominasi minimal maka terbukti bahwa $\gamma_{2}\left(\operatorname{Shack}\left(P_{3^{5}}, v, n\right)\right)=\gamma_{2}\left(P_{3^{5}}\right) n-$ $n+1$.

Teorema 5. Bilangan dominasi jarak dua pada graf Dodecahedral $P_{5^{3}}$ sebanyak $n$ salinan dengan operasi shackle titik adalah $\gamma_{2}\left(\operatorname{Shack}\left(P_{5^{3}}, v, n\right)\right)=\gamma_{2}\left(P_{5^{3}}\right) n-n+1$

\section{Bukti.}

Pembuktian bilangan dominasi jarak dua pada graf Dodecahedral juga Terdapat dua kemungkinan, yaitu $v \in S_{2}$ dan $v$ bukan elemen $S_{2}$ dengan $v$ adalah simpul penghubung (lingkage vertex) antara $P_{5^{3}}$ salinan ke- $i$ dan $P_{5^{3}}$ salinan ke- $i+1$, sedangkan $S_{2}$ adalah himpunan simpul pendominasi jarak dua pada graf $P_{5^{3}}$. Berikut akan diuraikan untuk masingmasing kasus.

Kasus 1. $v \in S_{2}$

Pada kasus dimana $v \in S_{2}$ untuk jumlah salinan ke-1 sampai salinan ke- $n$, bilangan dominasi jarak dua pada $\operatorname{Shack}\left(P_{5^{3}}, v, n\right)$ akan membentuk barisan aritmatika sebagai berikut.

$n=1 \rightarrow \gamma_{2}\left(P_{5^{3}}\right)$

$n=2 \rightarrow 2 \gamma_{2}\left(P_{5^{3}}\right)-2+1=2 \gamma_{2}\left(P_{3^{5}}\right)-1$

$n=3 \rightarrow 3 \gamma_{2}\left(P_{5^{3}}\right)-3+1=3 \gamma_{2}\left(P_{3^{5}}\right)-2$

$n=n \rightarrow \gamma_{2}\left(P_{5^{3}}\right) n-n+1$

Maka dengan menggunakan barisan aritmatika akan didapat bilangan dominasi jarak dua dari graf hasil operasi shackle titik sebanyak $n$ salinan adalah $\gamma_{2}\left(P_{5^{3}}\right) n-$ $n+1$. Selanjutnya akan dibuktikan bilangan dominasi tersebut dengan menggunakan induksi matematika sebagai berikut.

$$
\gamma_{2}\left(\operatorname{Shack}\left(P_{5^{3}}, v, n\right)\right)=\gamma_{2}\left(P_{5^{3}}\right) n-n+1
$$

Akan dibuktikan untuk $n=1$ adalah benar

$$
\begin{gathered}
\gamma_{2}\left(\operatorname{Shack}\left(P_{5^{3}}, v, 1\right)\right)=\gamma_{2}\left(P_{5^{3}}\right) \cdot 1-1+1 \\
\Leftrightarrow \gamma_{2}\left(P_{5^{3}}\right)=\gamma_{2}\left(P_{5^{3}}\right)
\end{gathered}
$$

Asumsikan untuk $n=k$ adalah benar

$$
\begin{gathered}
\gamma_{2}\left(\operatorname{Shack}\left(P_{5^{3}}, v, k\right)\right)=\gamma_{2}\left(P_{5^{3}}\right) \cdot k-k+1 \\
\Leftrightarrow \gamma_{2}\left(P_{5^{3}}, v, k\right)=\gamma_{2}\left(P_{5^{3}}\right) \cdot k-k+1
\end{gathered}
$$

Akan dibuktikan untuk $n=k+1$ juga benar

$$
\gamma_{2}\left(\operatorname{Shack}\left(P_{5^{3}}, v, k+1\right)\right)
$$

$$
\begin{aligned}
& =\gamma_{2}\left(\operatorname{Shack}\left(P_{5^{3}}, v, k\right)\right) \\
& +\operatorname{beda}
\end{aligned}
$$

$\Leftrightarrow \gamma_{2}\left(P_{5^{3}}\right) \cdot(k+1)-(k+1)+1=$

$\gamma_{2}\left(P_{5^{3}}\right) \cdot k-k+1+\gamma_{2}\left(P_{5^{3}}\right)-1$

$\Leftrightarrow \gamma_{2}\left(P_{5^{3}}\right) \cdot(k+1)-k-1+1=\gamma_{2}\left(P_{5^{3}}\right)$.

$k-k+1+\gamma_{2}\left(P_{5^{3}}\right)-1$

$\Leftrightarrow \gamma_{2}\left(P_{5^{3}}\right) \cdot(k+1)-k=\gamma_{2}\left(P_{5^{3}}\right) \cdot$

$(k+1)-k$

$\Leftrightarrow \gamma_{2}\left(P_{5^{3}}\right) \cdot k+\gamma_{2}\left(P_{5^{3}}\right)-k=\gamma_{2}\left(P_{5^{3}}\right) \cdot k+$ $\gamma_{2}\left(P_{5^{3}}\right)-k$

Dengan demikian terbukti bahwa pada kasus $v \in S_{2}$, operasi shackle titik pada graf Dodecahedral memiliki $\gamma_{2}\left(\operatorname{Shack}\left(P_{5^{3}}, v, n\right)\right)=\gamma_{2}\left(P_{5^{3}}\right) n-n+1$.

\section{Kasus 2. $v \notin S_{2}$}

Pada kasus dimana $v$ bukan elemen $S_{2}$ untuk jumlah salinan ke-1 sampai salinan ke- $n$, bilangan dominasi jarak dua pada $\operatorname{Shack}\left(P_{5^{3}}, v, n\right)$ akan membentuk barisan aritmatika sebagai berikut.

$n=1 \rightarrow \gamma_{2}\left(P_{5^{3}}\right)$

$n=2 \rightarrow 2 \gamma_{2}\left(P_{5^{3}}\right)$

$n=3 \rightarrow 3 \gamma_{2}\left(P_{5^{3}}\right)$

$n=n \rightarrow \gamma_{2}\left(P_{5^{3}}\right) \cdot n$

Maka dengan menggunakan barisan aritmatika akan didapat bilangan dominasi jarak dua dari graf hasil operasi shackle titik pada sebanyak $n$ salinan adalah $\gamma_{2}\left(P_{5^{3}}\right) \cdot n$. Berikutnya akan dibuktikan bilangan dominasi tersebut dengan menggunakan induksi matematika sebagai berikut. 


$$
\gamma_{2}\left(\operatorname{Shack}\left(P_{5^{3}}, v, n\right)\right)=\gamma_{2}\left(P_{5^{3}}\right) n
$$

Akan dibuktikan untuk $n=1$ adalah benar

$$
\begin{aligned}
& \gamma_{2}\left(\operatorname{Shack}\left(P_{5^{3}}, v, 1\right)\right)=\gamma_{2}\left(P_{5^{3}}\right) \cdot 1 \\
& \Leftrightarrow \gamma_{2}\left(P_{5^{3}}\right)=\gamma_{2}\left(P_{5^{3}}\right)
\end{aligned}
$$

Asumsikan untuk $n=k$ adalah benar

$$
\gamma_{2}\left(\operatorname{Shack}\left(P_{5^{3}}, v, k\right)\right)=\gamma_{2}\left(P_{5^{3}}\right) \cdot k
$$

Akan dibuktikan untuk $n=k+1$ juga benar

$$
\gamma_{2}\left(\operatorname{Shack}\left(P_{5^{3}}, v, k+1\right)\right)
$$$$
=\gamma_{2}\left(\operatorname{Shack}\left(P_{5^{3}}, v, k\right)\right)
$$$$
+ \text { beda }
$$

$\gamma_{2}\left(P_{5^{3}}\right)$

$$
\Leftrightarrow \gamma_{2}\left(P_{5^{3}}\right)(k+1)=\gamma_{2}\left(P_{5^{3}}\right) k+
$$

$$
\Leftrightarrow \gamma_{2}\left(P_{5^{3}}\right)(k)+\gamma_{2}\left(P_{5^{3}}\right)(1)=
$$

$\gamma_{2}\left(P_{5^{3}}\right) k+\gamma_{2}\left(P_{5^{3}}\right)$

$$
\Leftrightarrow \gamma_{2}\left(P_{5^{3}}\right)(k)+\gamma_{2}\left(P_{5^{3}}\right)=
$$

$\gamma_{2}\left(P_{5^{3}}\right) k+\gamma_{2}\left(P_{5^{3}}\right)$

Dengan demikian untuk $v \notin S_{2}$, hasil operasi shackle titik graf Dodecahedral memiliki $\quad \gamma_{2}\left(\operatorname{Shack}\left(P_{5^{3}}, v, n\right)\right)=\gamma_{2}\left(P_{5^{3}}\right) n$.

Dari kasus 1 dan 2 dapat diketahui bahwa $\gamma_{2}\left(P_{5^{3}}\right) n-n+1 \leq \gamma_{2}\left(P_{5^{3}}\right) n$ maka $\gamma_{2}\left(\operatorname{Shack}\left(P_{5^{3}}, v, n\right)\right)=\gamma_{2}\left(P_{5^{3}}\right) n-n+1$.

Selanjutnya akan dibuktikan bahwa $\gamma_{2}\left(\operatorname{Shack}\left(P_{5^{3}}, v, n\right)\right)=\gamma_{2}\left(P_{5^{3}}\right) n-n+1$

adalah jumlah simpul pendominasi minimal pada graf $\operatorname{Shack}\left(P_{5^{3}}, v, n\right)$. Andaikan $\left|S_{2} \operatorname{Shack}\left(P_{5^{3}}, v, n\right)\right|=\gamma_{2}\left(P_{5^{3}}\right) n-n+1-1$ maka simpul maksimal yang dapat didominasi oleh $\left|S_{2}\right|$ adalah

$$
\begin{gathered}
1+\left(N_{1}+N_{2}\right) n\left(\left[\frac{20 n-n+1}{1+\left(N_{1}+N_{2}\right) n}\right]\right) \\
\leq 1+\left(N_{1}+N_{2}\right) n \\
\left(\frac{20 n-n+1+\left(N_{1}+N_{2}\right) n}{1+\left(N_{1}+N_{2}\right) n}-1\right)=19 n
\end{gathered}
$$

Dengan demikian tidak semua simpul dapat didominasi, maka $\left|S_{2} \operatorname{Shack}\left(P_{5^{3}}, v, n\right)\right| \neq \gamma_{2}\left(P_{5^{3}}\right) n-n+1-1$. Karena $\gamma_{2}\left(P_{5^{3}}\right) n-n+1$ adalah jumlah simpul pendominasi minimal maka terbukti bahwa $\gamma_{2}\left(\operatorname{Shack}\left(P_{5^{3}}, v, n\right)\right)=\gamma_{2}\left(P_{5^{3}}\right) n-$ $n+$

\subsection{Studi Kasus Bilangan Dominasi Jarak Dua pada Peta Kebun Binatang Taman Safari Prigen}

Pada bagian ini akan dibahas mengenai morfologi peta Kebun Binatang Taman Safari Prigen untuk kemudian ditentikan bilangan dominasi jarak duanya. Peta Kebun Binatang Taman Safari Prigen dapat dilihat pada Gambar 2. Langkah awal adalah menentukan peta ke dalam sebuah graf. Kemudian gambar tersebut direpresentasikan menjadi graf, dimana pada graf tersebut persimpangan jalan direpresentasikan sebagai simpul dan setiap jalan direpresentasikan sebagai sisi. Representasi peta Kebun Binatang Taman Safari Prigen dapat dilihat pada Gambar 3. Dari representasi graf tersebut akan ditetapkan lokasi penempatan pos pengamanan pada simpul-simpul tertentu, sehingga dengan menggunakan Teori Bilangan Dominasi jarak 2 akan didapat jumlah pos pengamanan seminimal mungkin tanpa mengurangi efisiensinya.

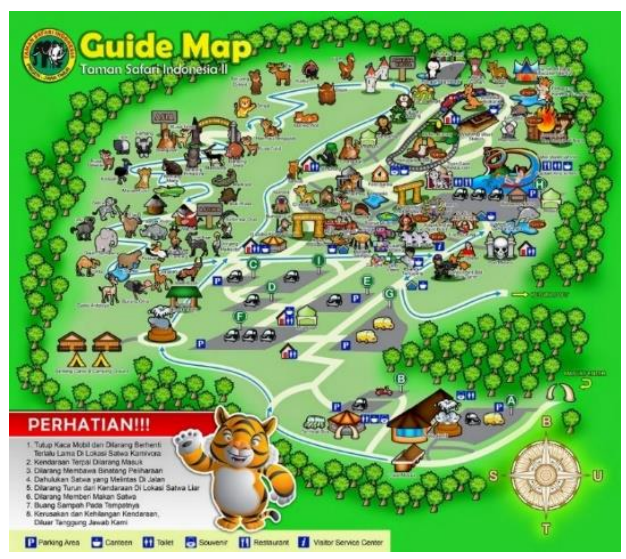

Gambar 2. Peta Kebun Binatang Taman

$$
\text { Safari Prigen }
$$

Berdasarkan analisis diperoleh bilangan dominasi jarak dua pada Peta Kebun Binatang Taman Safari Prigen sebanyak 10 simpul. Analisis dilakukan terhadap simpul-simpul pendominasi yang dapat mendominasi simpul terhubung berjarak maksimal dua. Simpul-simpul 
pendominasi tersebut dapat dilihat pada Gambar 3, yaitu simpul-simpul yang berwarna merah. Sehingga penempatan pos pengamanan dapat diletakkan pada simpul-simpul pendominasi dan hanya dibutuhkan 10 pos pengamanan pada Kebun Binatang Taman Safari Prigen.

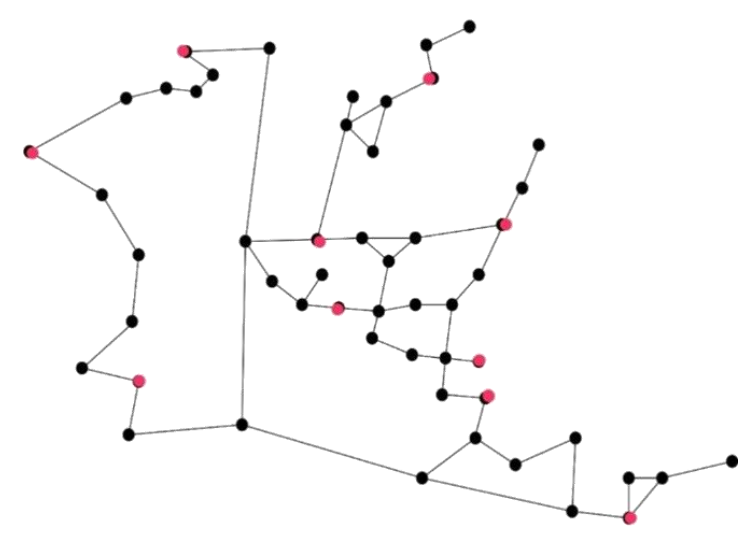

Gambar 3. Representasi Peta Kebun Binatang Taman Safari Prigen Serta Posisi Pos Pengamanan Menggunakan Bilangan Dominasi Jarak Dua

\section{KESIMPULAN}

a. Graf Platonik yang dioperasikan shackle titik sebanyak $n$ salinan terhadap dirinya sendiri memiliki bilangan dominasi jarak dua:

- $\quad \gamma_{2}\left(\operatorname{Shack}\left(P_{3^{3}}, v, n\right)\right)=\left\lceil\frac{n}{4}\right\rceil$

- $\quad \gamma_{2}\left(\operatorname{Shack}\left(P_{3^{4}}, v, n\right)\right)=\left\lceil\frac{n}{2}\right\rceil$

- $\gamma_{2}\left(\operatorname{Shack}\left(P_{4^{3}}, v, n\right)\right)=\gamma_{2}\left(P_{4^{3}}\right) n-n+1$

- $\gamma_{2}\left(\operatorname{Shack}\left(P_{3^{5}}, v, n\right)\right)=\gamma_{2}\left(P_{3^{5}}\right) n-n+1$

- $\gamma_{2}\left(\operatorname{Shack}\left(P_{5^{3}}, v, n\right)\right)=\gamma_{2}\left(P_{5^{3}}\right) n-n+1$

b. Representasi peta kebun binatang Taman Safari Prigen terdiri atas 53 simpul dengan menggunakan teori bilangan dominasi diperoleh 10 simpul dapat dijadikan sebagai pos pengamanan yang optimal karena dapat mengcover seluruh simpul dengan jarak maksimal dua.

\section{DAFTAR PUSTAKA}

Alif, A., 2013. Komputasi cerdas untuk pemula. Malang: ABC Press.

Berndtsson, M., Hansson, J., Olsson, B. \& Lundell, B., 2008. Thesis projects: a guide for students in Computer Science and Information Systems. 2nd ed. London: Springer-Verlag London Limited.

Broughton, J.M., 2002a. The Brettow Woods Proposal: a Brief Look. Political Science Quarterly, 42(6), p.564.

Broughton, J.M., 2002b. The Brettow Woods Proposal: a Brief Look. Political Science Quarterly, [ejournal] 42(6). Tersedia melalui: Perpustakaan Universitas BX $<$ http://perpustakaan.ubx.ac.id> [Diakses 1 Juli 2013]

Cakraningrat, R., 2011. Sistem pendukung Keputusan untuk UMKM. [ebook]. UBX Press. Tersedia melalui: Perpustakaan Universitas

$\mathrm{BX}$ $<$ http://perpustakaan.ubx.ac.id> [Diakses 1 Juli 2013]

Cox, C., Brown, J.T. dan Tumpington, W.T., 2002. What Health Care Assistants Know about Clean Hands. Nursing Today, Spring Issue, pp.64-68.

International Standards Office, 1998. ISO 690 - 2 Information and Documentation: Bibliographical References: Electronic Documents.

Samson, C., 1970. Problems of information studies in history. Dalam: S. Stone, ed. 1980. Humanities information research. Sheffield: CRUS.pp. 4468. 
Scottish Intercollegiate Guidelines, 2001. Hypertension in the elderly. (SIGN publication 20) [online] Edinburgh: SIGN (Diterbitkan 2001) Tersedia di:<http://www.sign.ac.uk/sign49.pdf $>$ [Diakses 22 November 2004]

Sommerville, I., 2011. Software engineering. 9th ed. London: AddisonWesley.

Tanenbaum, A.S., 1998. Organisasi Komputer Terstruktur, jilid 1. Diterjemahkan dari Bahasa Inggris oleh T.A.H Al-Hamdany. 2001. Jakarta: Salemba Teknika.

Undesa (United Nations Department of Economic and Social Affairs), 2005. 6th Global forum for reinventing government: towards participatory dan transparent governance. Seoul, Republic of Korea, 24-27 May 2005. New York: United Nations.

Undang-undang Republik Indonesia nomor 12 tahun 2012 tentang Pendidikan Tinggi. Jakarta: Kementerian Sekretariat Negara Republik Indonesia. 